\title{
Portuguese Ministers as Political Survivors: an empirical analysis of the first 20 Constitutional Governments
}

\begin{tabular}{l} 
Revista de \\
Sociologia \\
e Política \\
\hline
\end{tabular}

DOI 10.1590/1678-987320287306

\author{
Paulo Mourão' id e Vítor Domingues Martinho" it \\ 'Departament of Economics, Economics \& Management School, University of Minho, Braga, Portugal.

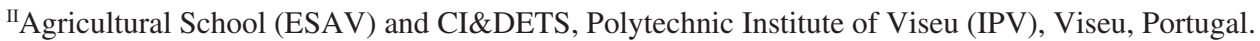

\begin{abstract}
Introduction: In this study, we evaluated the proportional risk of Portuguese Prime-Ministers and Ministers leaving office. Materials and Methods: We used consecutive days in office for each one of the 432 citizens who served in a ministerial function since 1976. Results: Exploring several divisions in this population, we concluded that individuals supported by parliamentary majorities, who served after 1986, who had higher educational credentials, and who were members of political parties exhibited lower risks of being exonerated. Conversely, being an aged person, serving during bad economic conditions, assuming several ministries simultaneously and being in charge of too-specific ministries did not ensure longer political tenures for Portuguese ministers. Discussion: Besides being the first empirical assessment of all Portuguese Ministers after 1974, this work shows how higher skills are important assets for Ministers' tenures and how economic crises are highly stimulating for cabinets' changes in Portugal, which corresponds to the pattern observed in most recent democratic regimens.
\end{abstract}

KEYWORDS: ministerial cabinet; Portuguese constitutional governments; determinants of political survival; proportional hazard; gender.

Received in June 24, 2019. Approved in December 28, 2019. Accepted in December 29, 2019.

\section{I - Introduction ${ }^{1}$}

\footnotetext{
${ }^{1}$ Acknowledgments: This work is financed by national funds through FCT - Fundação para a Ciência e Tecnologia, I.P., under the project UID/Multi/04016/2019. Furthermore we would like to thank the Instituto Politécnico de Viseu and CI\&DETS for their support. This work is supported by national funds, through the FCT - Portuguese Foundation for Science and Technology under the project UID/SOC/04011/2019.

2 We can identify the study of Castro and Martins (2013) as a comparable research if we consider the Portuguese focus. Nevertheless, the study of Castro and Martins (2013) focuses on Portuguese local governments' tenure while ours focuses on ministerial tenures.
}

I n this article, we examine the political survival of Portuguese Ministers using Proportional Hazards (PH) regressions. We observed all Prime-Ministers and Ministers holding ministerial offices since 1976, i.e., since the establishment of the Constitutional Governments. Therefore, we observed more than 400 individuals. These individuals exhibit considerable heterogeneity in terms of their days in office - from the record minimum ( 8 days) held by Henrique Chaves (in 2004) to the record maximum of 5543 days held by Lino Miguel (who achieved this in 1991).

We expect this piece of research will fill part of the gap in the literature focused on the study of the political survival rates of Portuguese Prime-Ministers and Ministers. As it can be easily checked, there is not a comparable study to this one in terms of the extension of the number of Portuguese ${ }^{2}$ individuals so studied and recurring to a so enlarged set of dimensions. In any case, although with other approaches, the work of Almeida and Pinto (2002) that analyzed the evolution of the composition and recruitment of ministers in Portugal, since 1851 until 1999, also deserves to be quoted as methodologically close. Understanding better the socio-economic dimensions, the individual characteristics and the political variables interfering in the political survival of Portuguese Prime-Ministers and Ministers is also relevant for two additional stimuli. The first stimulus relates to the opportunity of testing some discussed hypotheses from the literature, namely the importance of the parliamentary majority or the relevance of the political background/experience for enhancing the political survival of the ministers. The second stimulus regards the opportunity of detailing the present list of works about the Portuguese Constitutional Democratic 
Regimen with a methodological discussion which will let the future research with the possibility of observing if the differences between gender, university degrees or party affiliation will change in face of the findings here debated.

Combining the literature with our empirical observations, we tested three groups of variables that may be responsible for the diverse survival rates that we identified. Because they are appointed by the Prime-Minister, we hypothesized that ministers remain in office as long as they continue to add value to the goals of the Prime-Minister and to the remaining governmental staff. Therefore, the first group of variables will be composed of variables characterizing the political environment of the government. The second group of possible determinants relates to the socio-economic context of the minister's tenure. Finally, the third group of determinants is composed of the individual characteristics of each minister (e.g., gender, age, or education).

However, we also employed two different divisions of the minister's duration in office. First, we observed whether a minister exits his/her office during a term; second, we observed whether he/she finishes his/her tenure but returns years later for a new term (as in the case of the 'political animals' who collect several positions as ministers of different governments).

The remainder of this paper is structured as follows. Section II introduces the process of nomination and exoneration of Portuguese Ministers in the Constitutional Governments. In this section, the relevant literature is also reviewed. Section III presents the empirical findings we obtained for our PH regressions, including three different distributions for survival time (Exponential, Weibull and Gompertz). We have also performed robustness checks, extending our analysis to different groups of ministries. Finally, section IV concludes and presents some political implications of our results and some further challenges for this line of research.

\section{II - Portuguese Ministers as Political Survivors - Legislation and Literature}

II.1 - Some proposals from the literature to construct the set of variables influencing the duration of Portuguese ministers in office

Now, we construct a testable set of dimensions to explain the heterogeneous duration of Portuguese ministers within each term. Etymologically, the word 'minister' comes from the Latin De Minus, associated with a person who was under the authority of a Magis. Therefore, ministers' duration in office depends on the interest of the inviting Prime Minister and on the interests of the supporting political forces. Additionally, we also test the relevance of the evolution of economic and political forces to the number of days served by Portuguese Ministers. Finally, we also include individual characteristics (such as age, education, and the density of birthplaces), which have been shown to be relevant in other international studies, as for example Almeida and Pinto (2002). It is expected that frameworks without pressures from the media (because scandals, for instance), with good socioeconomic conditions and where the ministers have more experience and education credentials promote more governmental stability.

\section{II.1.1 - A Minister as a trusted Principal}

Portuguese Ministers are Portuguese citizens recommended by the PrimeMinister to the President of the Portuguese Republic to perform the functions related to ministries' incumbency. Therefore, we can assume that there is political trust between the Prime-Minister and the recommended and proposed Ministers, bearing in mind the political profile of the citizen, the nature of the 
Ministry that will be delegated to the Minister, and the evolving socio-economic context. However, these contexts may be disturbed by socioeconomic circumstances and by the pressure of the opposition parties.

Following the discussions of authors such as Bucur (2013) and Leruth and Paul (2006), models of the problem of principal-agent behavior can be used to observe the evolution of the political relationship between Prime-Ministers (the "principals") and their Ministers (the "agents"). Consequently, "hard" ministries tend to be given to experienced politicians and/or to highly loyal Ministers (in the perspective of the Prime-Ministers). The selection of ministers across the world countries with diverse political realities was explored, for instance, by Dowding and Dumont (2016).

In the end, for the Portuguese context, the economic conditions, be member/or not of a party, the particularities of the ministries, the age and the educational credentials seem to be the main factors that influence the ministerial survival.

Therefore (Bright et al., 2015), Ministries focused on Welfare issues (such as the Ministry of Social Security or the Ministries of Work, Health or Educational Affairs) may tend to offer their incumbents a longer duration of political office. The reasons are related to the motivations of popularity that must be managed by the chiefs of government (Silva, 2015) combined with the importance of Welfare policies to most of the major parties of western economies (Druckman and Warwick, 2005). As previously discussed, we follow Bright et al. (2015), and in further research we will consider the following groups of ministries (Druckman and Warwick, 2005):

- Strategic Ministries: Vice-Prime-Ministry; Presidency; Finance; Home Affairs; Parliamentary Affairs; and Foreign Affairs;

- Ministries of Social/Welfare Issues: Health; Education; Social Affairs; Work/Employment; Social Security; Housing; and Social Equipment;

- Ministries focused on specific Affairs: Environment; Culture; Science; Public Works; Commerce and Tourism; Industry; Defense; Justice; Economy; Youth and Sports; Transportation; Sea Affairs; and Agriculture;

- Ministries focused on specific Policies: Quality of Life; European integration; Administrative Reform; Equality;

- Ministries of the Republic for the Autonomous Regions of the Azores and Madeira.

Holding different ministries is an important challenge for any politician because it leads to broadening the focus of the Minister, which can put extraordinary pressure on his/her political performance (Berlinski et al., 2007). However, holding different ministries can also be interpreted as a sign of the political trust attributed to such politicians (Almeida, 2008), which tends to increase the political responsibility (of such ministers). As a result, following Bright et al. (2015), holding different ministries can produce ambiguous results. On the one hand, it may increase the survival rate of ministers who simultaneously hold different ministries due to the combined responsibility attributed to such intensity. On the other hand, the minister holding different ministries may suffer an increased erosion of popularity due to his or her greater exposure to an enlarged potential criticism (Berlinski et al., 2007).

The number of days a minister serves in office essentially depends on the added value of his/her presence to the political survival of the supporting gov- 
ernment, and it also depends on the duration of this supporting government. Although the perception of added value has been discussed in the literature by Druckman and Warwick (2005) (suggesting that this perception is a mixed result of the minister's popularity combined with the political relevance/strength of his/her profile and competence in managing various issues), the duration of the government has been much more extensively analyzed in the literature.

Authors like Chiru (2015) have emphasized how being in a government supported by a parliamentary majority lengthens a minister's duration in office. In contrast, a government facing an effectively threatening parliamentary opposition (for instance, an opposition that has obtained the minimum number of votes required to approve a "rejection motion") has a higher risk of being overthrown (Constitution of the Portuguese Republic, 1976).

Following Han (2015), we also consider the dominant political wing in the Portuguese Parliament. Although certain works (Correa d'Almeida \& Mourao, 2015) suggest the absence of significant differences in the Public Finances of Portugal due to the different dominating political wings (Left or Right) in the Government, other studies reveal other differences. Among these works (Richardson, 2001), we observe that it may be more likely for Right-wing (supported) governments to minimize cabinet changes. The rationale is based on the political tradition of assuming more cohesion in Right-Wing governments, which minimizes cabinet changes.

II.1.2 - "It's the Economy"

Economic conditions do influence voters' perceptions of the incumbents' competence as well as that of other politicians. Since Downs (1957), a vast number of works have detailed the influence of economic issues on voters' perceptions - economic issues such as unemployment levels (Fielding, 2000), the evolution of inflation rates (Mourao, 2013), changes in the system of social assistance (Hessami, 2010), modifications to the tax structure (Akarca and Andrianacos, 2006), and even the evolution of terms of trade and/or exchange rates (Mayer and Raimondos-Møller, 2003). In Portugal, the works of Veiga and Veiga (2003) can also be seen as focusing on the influence of economic conditions on politicians' popularity .

Following the literature based on Veiga and Veiga (2003), we can hypothesize that increases in the growth rate of the country, higher levels of real GDP per capita, and low unemployment and/or inflation rates will increase the number of days that each minister and each government is in power. We also highlight that, following Fielding (2000), Hardouvelis and Thomakos (2008) and Fischer et al. (2012), voters and politicians are more sensitive to changes in these macroeconomic indicators than to the levels of these indicators. However, as Fischer et al. (2012) observe, even if the economic context is not the most favorable, Prime Ministers may opt to postpone cabinet reshuffling to project an image of cohesion/unity to the public and to the political opposition.

Certain authors, such as Bright et al. (2015), have suggested that we must consider "long term" political-economic cycles to analyze the survival of ministers, incumbents and governments. Actually, Berlemann and Enkelmann (2014) also found that the length of the period considered in the sample influences the effect of economic variables on the politician popularity. In any case, the economic dynamics have implications in the political contexts. However, these effects are dependent on factors as the national economy and the institutional changes (Lewis-Beck and Stegmaier, 2013). For instance, political institutions characterized by successive parliamentary dissolutions, political turmoil or abrupt regime changes significantly reduce the political longevity of those as- 
suming political functions. In contrast, stable political institutions tend to provide better chances for those who have assumed political functions to maintain their offices (Mattozzi and Merlo, 2005). In Portugal, in the political climate since 1974, several works have identified the year 1986 (the entrance of Portugal to the European Economic Community and the beginning of the first majority ruled by the right-wing Prime Minister Anibal Cavaco Silva) as a structural break in the level of political and government stability. As Mourao and Martinho (2016), Veiga and Veiga (2001) and Carneiro et al. (2009) have found, 1986 is an important year in recent Portuguese economic history.

\section{II.1.3 - The right (wo)man in the right place at the right moment}

Without intending to be tautological, we note that the success of a Minister, measured by his or her number of days in office, is also dependent on his or her individual characteristics. Our review of the literature posits that in addition to age (Fischer et al., 2012) and gender (Fischer et al., 2012), other influential factors relate to the social network/social capital of the minister's primary groups (relatives and friends), as claimed by Savage et al. (2004). Also important is his or her level of individual probity and competence, proxied by the higher university degrees that he/she holds (Seyd, 2015; Rose, 2014).

Some proxies useful for measuring the social capital around a politician have been found to be the socioeconomic dimensions of his/her birthplace and/or of his/her place of residence (as Abrantes and Roldão (2014) show, suggested by the population density of these places), as well as his/her party's affiliation (Almeida, 2008).

However, grounded in a longer tradition (see authors such as Bright et al., 2015), we also identify the relevance of past political experience in enhancing a politician's political longevity. Therefore, we can hypothesize that individuals who had previously been members of governments will face lower risks of being prematurely fired after assuming new functions in governments' cabinets. In this same line of thought, the literature on "political animals" argues that, as in sports or in biology, competitive and ambitious individuals, who have collected past (and mostly victorious) experiences, have higher probabilities of succeeding in competitive environments, i.e., in government offices (Wissenburg and Schlosberg, 2014).

Table 1 exhibits the suggested dimensions proposed by the various works that we have reviewed and their expected effects on the proportional hazard of Portuguese Ministers finishing their tenures. Table 1 also presents the sources of our data regarding these variables.

We start by detailing that the all data were obtained from the following sources: CVCE (2016); FFMS (2016); INE (2016); Pordata (2016); Reto and Sá (2016); and Sardica (2011). Following the literature, we considered the following variables: yearly GDP real growth rate; yearly change in unemployment rate; yearly change in inflation rate; member/or not of a political party (dummies); number of past functions as a member of the government; number of ministries simultaneously held by the same minister; population density (of each minister's birthplace); education level (1, Bachelor; 2, Master's Degree; 3, Ph.D. Degree; 4, Full Professor); gender (dummies); parliamentary majority (dummies); \% right-wing seats; age (of each minister at each observation); and period after/before 1986 (dummies). 
Table 1 - Synthesis of the variables suggested in the literature as determinants of ministers' duration in office

\begin{tabular}{|c|c|c|c|}
\hline Variable/Proxy & Main authors & $\begin{array}{l}\text { Expected effect on the pro- } \\
\text { portional hazard of incum- } \\
\text { bents/ministers exiting office }\end{array}$ & Source of our data \\
\hline Yearly GDP real growth rate & $\begin{array}{l}\text { Fielding (2000); Veiga and } \\
\text { Veiga (2003) }\end{array}$ & - & PORDATA (2016) \\
\hline $\begin{array}{l}\text { Yearly Change (increase) in } \\
\text { unemploym. rate }\end{array}$ & $\begin{array}{l}\text { Fielding (2000); Veiga and } \\
\text { Veiga (2003) }\end{array}$ & + & PORDATA (2016) \\
\hline $\begin{array}{l}\text { Yearly Change (increase) in } \\
\text { inflation rate }\end{array}$ & $\begin{array}{l}\text { Fielding (2000); Veiga and } \\
\text { Veiga (2003) }\end{array}$ & + & PORDATA (2016) \\
\hline Member of a political party & $\begin{array}{l}\text { Almeida (2008); Fischer et al. } \\
\text { (2012) }\end{array}$ & - & SS \\
\hline $\begin{array}{l}\text { Number of past functions as a } \\
\text { member of the Government }\end{array}$ & $\begin{array}{l}\text { Almeida (2008); Fischer et al. } \\
\text { (2012); Bright et al. (2015) }\end{array}$ & - & SS \\
\hline $\begin{array}{l}\text { Number of ministries simulta- } \\
\text { neously holding by the same } \\
\text { minister }\end{array}$ & $\begin{array}{l}\text { Bright et al. (2015); Berlinski et } \\
\text { al. (2007) }\end{array}$ & $-/+$ & SS \\
\hline Density (birthplace) & Abrantes and Roldão (2014) & - & INE (2016) \\
\hline Education level & $\begin{array}{l}\text { Fischer et al. (2012); Abrantes } \\
\text { and Roldão (2014) }\end{array}$ & - & SS \\
\hline Gender & Fischer et al. (2012) & $+/-$ & SS \\
\hline Parliamentary Majority & Chiru (2015) & - & PORDATA (2016) \\
\hline$\%$ right-wing seats & Almeida (2008); Han (2015) & $+/-$ & PORDATA (2016) \\
\hline Age & Fischer et al. (2012) & $+/-$ & SS \\
\hline After 1986 & $\begin{array}{l}\text { Veiga and Veiga (2003); Afonso } \\
\text { (2013); Carneiro et al. (2009) }\end{array}$ & - & \\
\hline
\end{tabular}

Source: elaborated by the authors. SS Several Sources (including CVCE, 2016; FFMS, 2016; Reto and Sá, 2016; Sardica, 2011).

II.2 Studying the political survival of Portuguese Prime-Ministers and Ministers - some descriptive comments

We are going to study only the period of Constitutional Governments in Portugal in this paper. The first Constitutional Government was established in 1976 with Mario Soares as Prime Minister. This was the first government supported by a national Parliament elected after the approval of the Constitution of 1976 on the $2^{\text {nd }}$ of April. Between the Carnation revolution $\left(25^{\text {th }}\right.$ of April, 1974) and the first day of the First Constitutional Government (23 $3^{\text {rd }}$ of July, 1976) there were six Provisory Governments. These Provisory Governments were directly nominated by the President of the Republic, without observing the composition of the National Parliament. Therefore, to avoid the insertion of sample biases, we will concentrate our analysis on the period after 1976, in which the parliamentary composition was clearly associated with the duration of the Portuguese Governments.

After collecting official data for all the 419 Portuguese citizens who held positions related to 453 Ministerial offices and for all 13 citizens who led the 20 Constitutional Governments (until 2015), we can share some preliminary observations. Following the values shown in Table 2, we observe that the mean value for the duration of ministerial functions is 368 days (423 for Prime-Ministers, PM, and 366 for Ministers).

The year 1986 has historically constituted a natural structural break when characterizing the recent period of Portuguese democracy (Mourao and Martinho, 2016). In addition to being the year of Portugal's entrance into the Euro- 
Table 2 - Descriptive statistics on the days in tenure and on the cumulated days in ministerial office of Portuguese Ministers (1976 -2015)

\begin{tabular}{|c|c|c|c|c|c|}
\hline & \multicolumn{5}{|c|}{ Days in tenure } \\
\hline & $\mathbf{N}$ & Mean & Std. Dev. & Min & Max \\
\hline All sample & 1509 & 368.4983 & 338.5155 & 8 & 1689 \\
\hline Prime-Minister & 63 & 422.81 & 430.4 & 27 & 1689 \\
\hline Minister & 1446 & 366.13 & 333.92 & 8 & 1689 \\
\hline Before 1986 & 620 & 261.9742 & 189.1566 & 28 & 881 \\
\hline After 1986 & 889 & 442.7897 & 395.2362 & 8 & 1689 \\
\hline Women & 120 & 383.8417 & 358.5747 & 27 & 1689 \\
\hline Men & 1374 & 364.3981 & 333.2392 & 8 & 1689 \\
\hline Parliamentary Minority & 639 & 283.9624 & 263.1261 & 13 & 1458 \\
\hline Parliamentary Majority & 870 & 430.5885 & 372.7069 & 8 & 1689 \\
\hline Left & 867 & 320.7797 & 324.0084 & 13 & 1689 \\
\hline Right & 642 & 432.9408 & 347.1559 & 8 & 1592 \\
\hline
\end{tabular}

Source: elaborated by the authors.

pean Economic Community, it was also the year of the first stable parliamentary majority of the country, which brought significant changes to the functioning of Portugal's political institutions (Carneiro et al., 2009).

Before 1986, the Ministers with the most days in office per term were the Ministers of the government under Prime-Minister Mário Soares, during the period from the $9^{\text {th }}$ of June, 1983 to the $6^{\text {th }}$ of November, 1985 (most of these ministers had tenures of 881 days). During this period (1976-1986), the record for the minimum length of time in ministerial office is held by A. Oliveira e Silva (Minister of Home Affairs in the $2^{\text {nd }}$ Constitutional Government), 28 days.

In terms of total days in office (including more than one government), Lino Miguel (Minister of the Republic for the Autonomous Region of the Madeira) holds the record with 3413 days in 1985. In contrast, the already-mentioned A. Oliveira e Silva (Home Affairs) had the lowest number of accumulated days in office (28 days).

After 1986, the highest values per tenure (1689 days in 2009) are those of the Ministers of the government under Prime-Minister José Sócrates during the period from the $12^{\text {th }}$ of March, 2005 to the $26^{\text {th }}$ of October, 2009. Regarding accumulated days in office, Lino Miguel (Minister of the Republic for the Autonomous Region of the Madeira), was again the citizen with the most accumulated days in office (a total of 5543 days). Henrique Chaves (Youth, Sports and Rehabilitation) had the lowest number of days (8 days in 2004).

When we consider men versus women, the mean for men tends to be higher than for women, whether for days in term or for accumulated days in office. Margarida Marques de Almeida (Education Minister) and Teresa Morais (Minister of Culture) had the shortest tenures ( 27 days, from $30^{\text {th }}$ of October of 2015 to $26^{\text {th }}$ of November of 2015). In terms of the longest tenures, Maria de Lurdes Rodrigues (Education) was the Portuguese woman serving the highest number of continuous days in a ministerial term (1689 days, from 2005 until 2009) and Manuela Ferreira Leite (Finance) was the woman with the most accumulated days (she accumulated 2426 days in 2004).

Recalling that, in fact, we observed 13 different Prime-Ministers and 419 different Ministers for 20 governments (23/7/1976/ - 26/11/2015). The number 
of observations relate to multiple yearly observations made for each individual (at least 3 observations: starting date in office, medium term, and exit date). The descriptive statistics of the variables are provided in Table 3.

Briefly commenting on Table 3, we observe that the yearly growth rates of real GDP per capita, unemployment and inflation have significant oscillations. For the growth rate of real GDP per capita, the minimum value $(-3.6 \%)$ occurred in 2012 and the maximum value $(+8.1 \%)$ is associated to with the year 1990. The maximum values of the changes in unemployment and inflation rates were observed in $1993(+33.3 \%)$ and $2011(+160.4 \%)$, respectively. Approximately $67 \%$ of Portuguese Ministers were members of political parties and approximately 92\% were men (as also Soares, 2016, identified). The maximum number of past ministerial functions was observed, indeed, for Lino Miguel (Minister of the Republic for the Autonomous Region of Madeira) when he accepted his positions in the $11^{\text {th }}$ Constitutional Government (in 1991). Education level is a variable taking discrete values characterizing the highest education degree held by the Minister (1, Bachelor; 2, Master's Degree; 3, Ph.D. Degree; 4, Full Professor). The minimum percentage of right-wing seats was recorded in the $17^{\text {th }}$ Constitutional Government, 2005-2009) and the maximum percentage of right-wing seats in the National Assembly was recorded during the $2^{\text {nd }}$ majority of Cavaco Silva (12 ${ }^{\text {th }}$ Constitutional Government, 1991-1995). The mean age for a Portuguese Minister starting his/her tenure is 55.8 years. Finally, several ministers simultaneously managed three different ministries (the maximum number of simultaneously managed ministries); for instance, Jorge Coelho achieved this record in the year 2000.

Moving to a more focused empirical analysis of the duration of Portuguese Prime-Ministers and Ministers in the Constitutional Governments, we will will consider the number of consecutive days in office of each individual (PM or Minister) within each term. A proper indicator of the survival rate is provided by the Kaplan-Meier Survival Probability estimate (Berlinski et al., 2007; Bright et al., 2015) for the period of $t$ days, given by

Table 3 - Descriptive statistics of the covariates

\begin{tabular}{lccccc}
\hline Variables & $\begin{array}{c}\text { Number of } \\
\text { observations }\end{array}$ & Mean & $\begin{array}{c}\text { Standard } \\
\text { Deviation }\end{array}$ & Minimum & Maximum \\
\hline Yearly GDP real growth rate (\%) & 1429 & 2.381 & 2.611 & -3.638 & 8.095 \\
Yearly Change in unemploym. Rate (growth rate), \% & 1509 & 5.382 & 25.377 & -26.86 & 33.342 \\
Yearly Change in inflation rate (growth rate), \% & 1429 & -12.800 & 53.303 & -267.86 & 160.45 \\
Member of a political party & 1493 & 0.669 & 0.471 & 0 & 1 \\
Number of past functions as a member of the Government & 1350 & 0.966 & 1.374 & 0 & 10 \\
Density (birthplace) & 1392 & 3931.89 & 3798.63 & 9.7 & 9550.1 \\
Education level & 1365 & 1.765 & 1.092 & 1 & 4 \\
Gender, dummy (Man=1) & 1493 & 0.919 & 0.271 & 0 & 1 \\
Parliamentary Majority, dummy & 1509 & 0.576 & 0.494 & 0 & 1 \\
\% right-wing seats & 1509 & 44.55 & 5.890 & 36.01 & 56.71 \\
Age & 1499 & 55.871 & 11.772 & 36 & 78 \\
Year After 1986 (dummy) & 1509 & 0.589 & 0.492 & 0 & 1 \\
Number of ministries simultaneously holding & 1499 & 1.255 & 0.512 & 1 & 3 \\
\hline
\end{tabular}

Source: elaborated by the authors. 


$$
S_{t}=\frac{\text { Holding }_{t}-\text { Dismissed }_{t}}{\text { Holding }_{t_{0}}}
$$

where $t_{0}$ refers to the starting period.

Suppose that we observed 1000 individual cases. Only 400 of them retained their ministerial charge for a period of 250 days. Then, $S_{250}=(1000-600) / 1000$ $=0.400 ; 150$ of the "surviving" 400 individuals were dismissed before 500 days; so, $S_{500}=250 / 1000=0.250$, and so on. In a more formal way, we can write

$$
S\left(t_{i}\right)=\prod_{t_{i}<t}\left(1-\frac{d_{i}}{n_{i}}\right)
$$

meaning that the Kaplan-Meier Survival Probability estimate for the period $t_{i}$ is the product operator for the successive survival rates observed for the previous periods. For instance, recalling our example, $S_{500}=0.400 *(250 / 400)=0.250$.

Considering the different survival rates for the different periods, we present the Kaplan-Meier estimates for the 432 individuals we studied (Figures 1-5). Figures 1-5 consider some of the classical divisions suggested by the literature review for analyzing the survival capacities of political leaders and politicians in office (being PM or only a Minister, holding the office before or after 1986, gender, and type of parliamentary majority).

Figures 1-5 exhibits the Kaplan-Meier survival estimates considering consecutive days in office ${ }^{3}$.

We also run the proper tests of equality across the different strata generated by the partitions that we used for these preliminary steps (Ministers vs PrimeMinisters, Before vs After 1986, Women vs Men, Parliamentary Minority vs Parliamentary Majority, and Left vs Right-wing majority). A p-value close to zero means that we cannot expect a significant similarity in survival curves between those individuals belonging to one stratum and those belonging to another. For running the tests of equality across the different strata we used three tests - log-rank, Wilcoxon-Breslow-Gehan, and Peto-Peto - and have included the $\mathrm{p}$-values below each figure.

Figura 1 - Political survival of individuals being Prime-Ministers (PM) or only a Minister

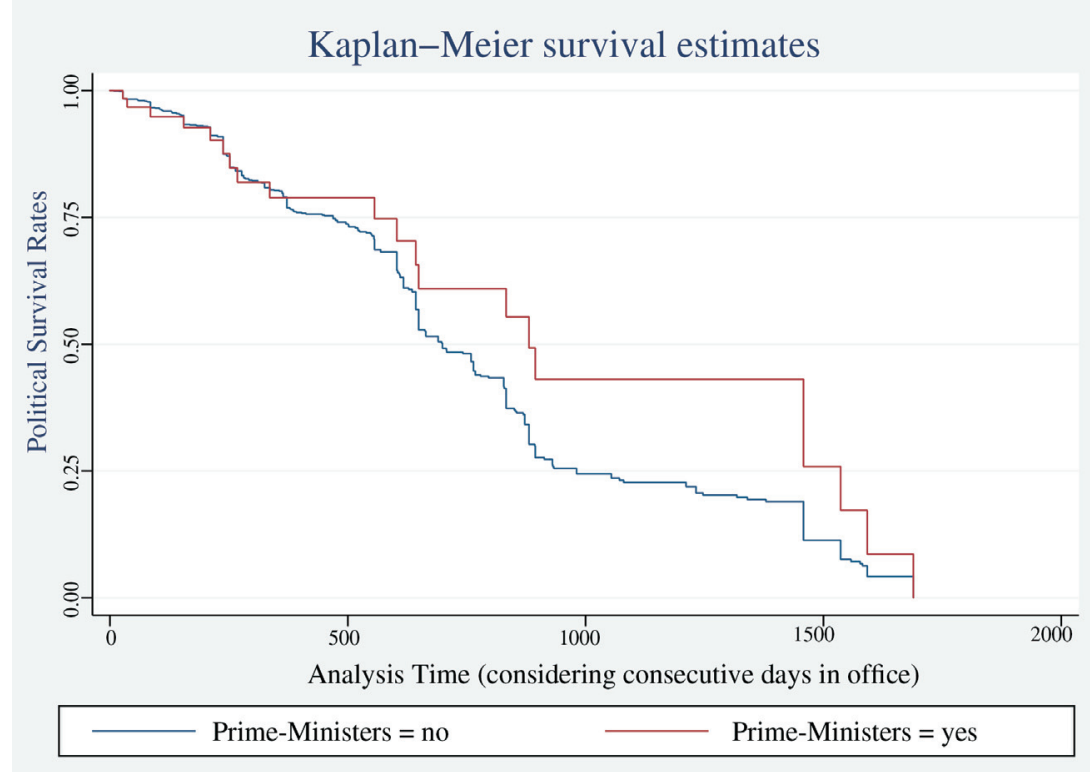

Source: elaborated by the authors. 
Figura 2 - Political survival of individuals holding the office before or after 1986

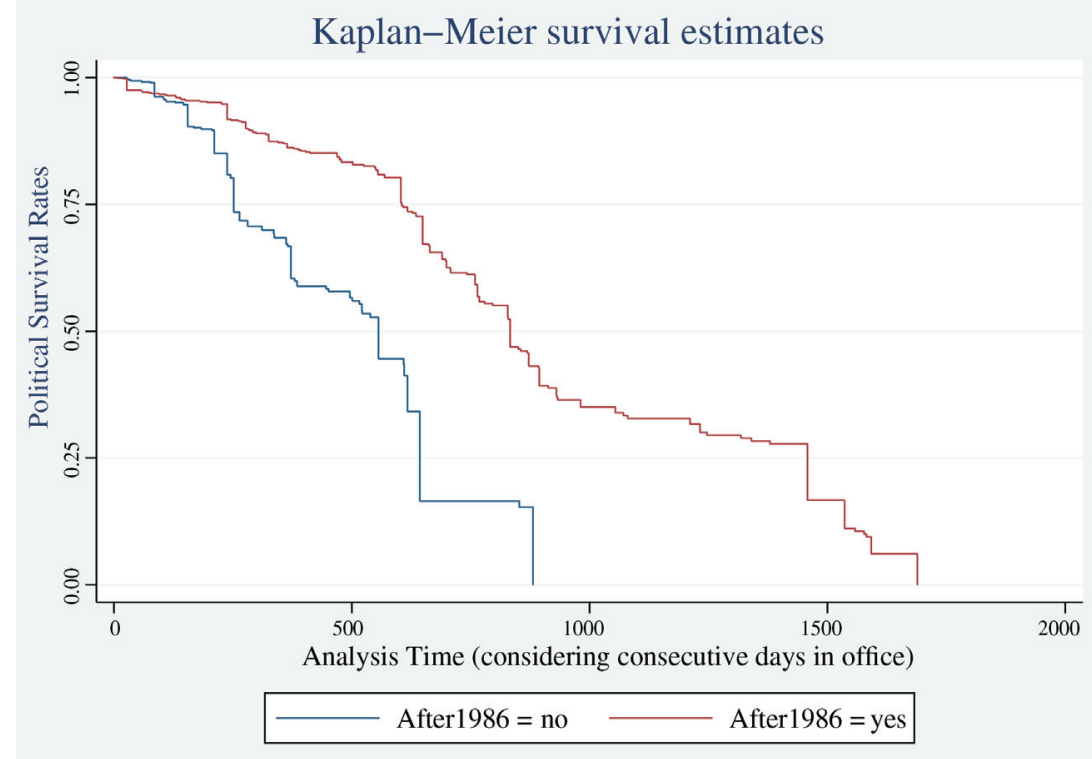

Source: elaborated by the authors.

Figura 3 - Survival rate tends to be higher for women until approximately 800 days in office

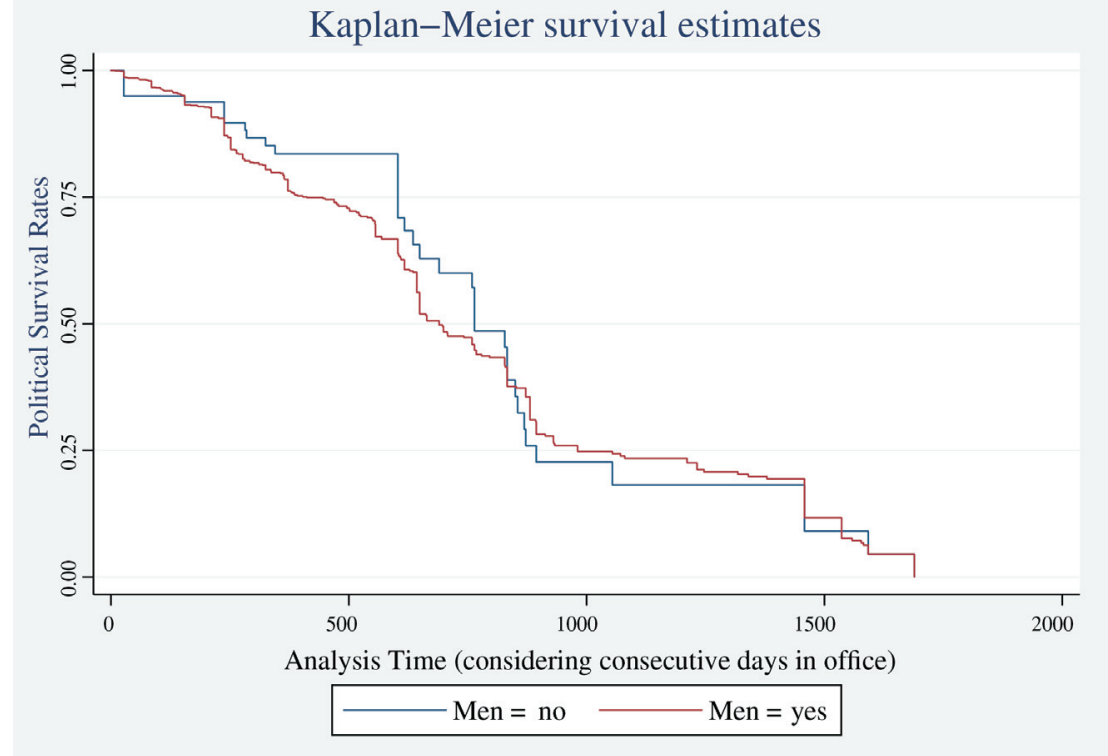

Source: elaborated by the authors.

The different figures do let us clearly identify higher political survival rates for individuals holding office in governments supported by parliamentary majorities (Figure 4), especially by right-wing majorities (Figure 5).

Based on this first insight, we also observed that the political survival of individuals in ministry offices increased after 1986 (Figure 2), and this survival rate tends to be higher for women until approximately 800 days in office (Figure 3). 
Figura 4 - Political survival rates for individuals holding office in governments supported by parliamentary majorities

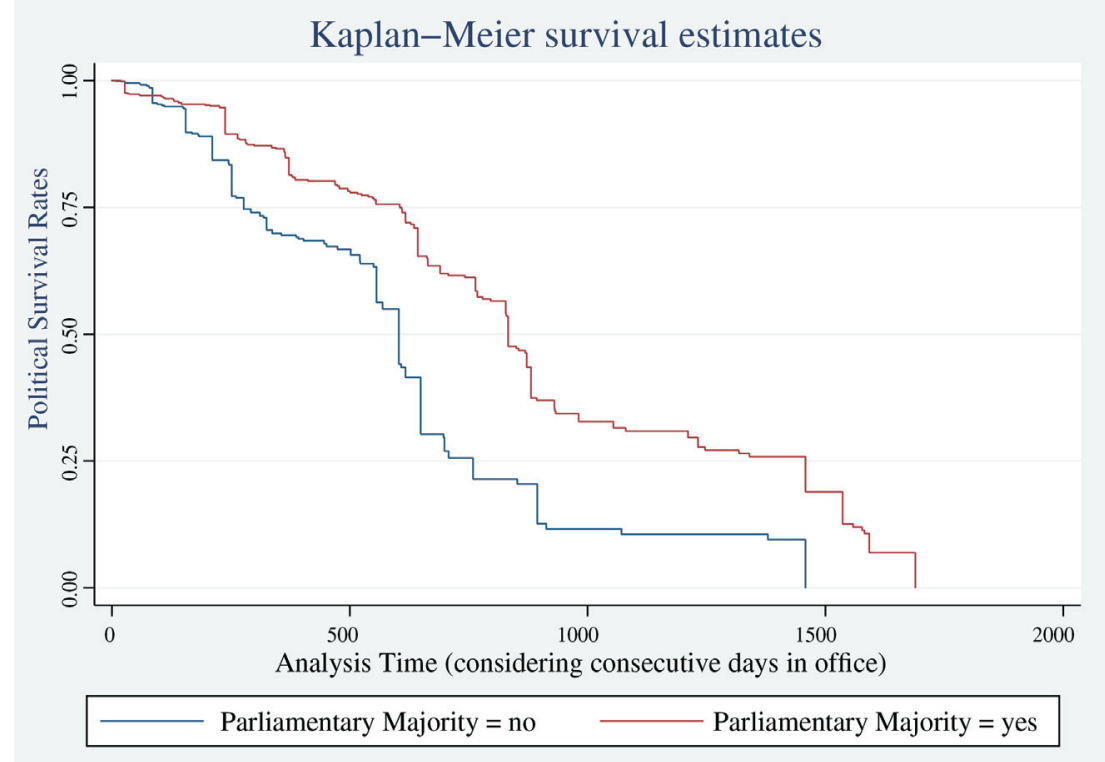

Source: elaborated by the authors.

Figura 5 - Political survival rates for individuals holding office in governments supported by right-wing majorities

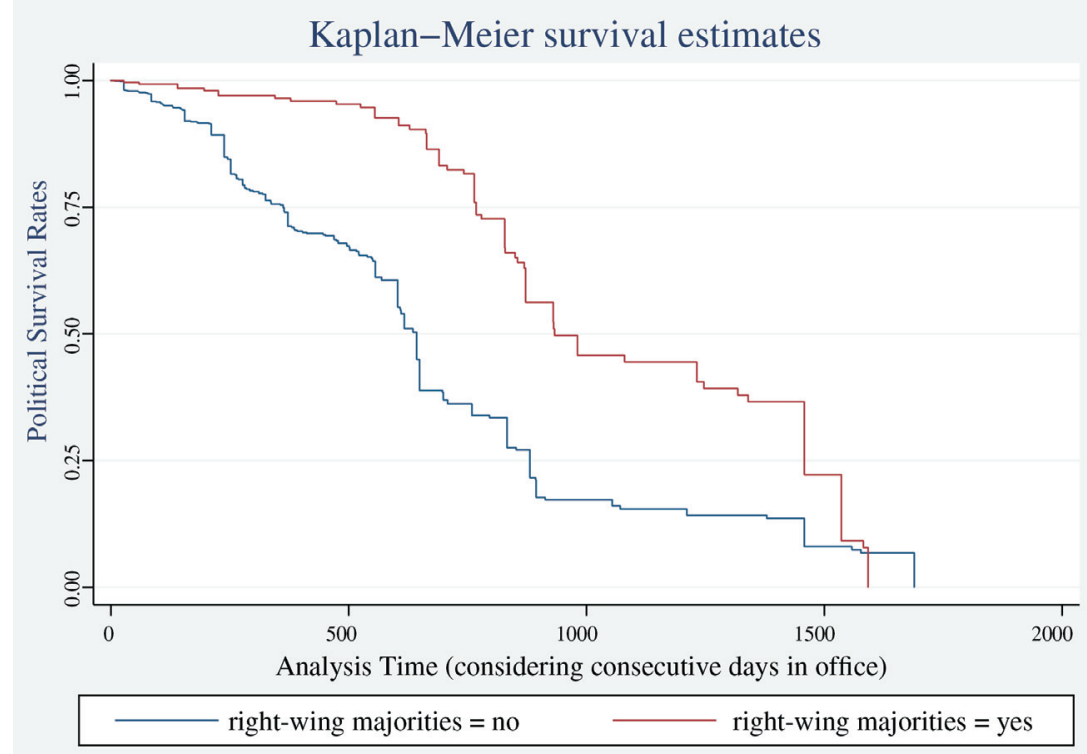

Source: elaborated by the authors.

II.3 Motivation of the work

Therefore, starting from these motivating observations, we investigate the determinants affecting the changes in political survival rates among ministers in Portugal since 1976. There are three major motivations supporting this effort.

First, this study is pioneering the study of the political survival rates of Portuguese Ministers and Prime Ministers. It can be quickly confirmed by review- 
ing the literature that there have been very few attempts to study so many individuals by focusing on their various details and trying to test determinants of their highly heterogeneous survival rates.

Second, we will test a robust set of hypotheses that the literature on political science and economics has suggested and tested for other western democracies and Mediterranean countries (Fedeli et al., 2014).

Finally, we are going to observe each individual (/Minister) in two types of duration already identified. The first type relates to his/her duration within each form of ministerial tenure, a standard measure (Fernandes and Magalhaes, 2015). However, we realize that there are those cases which are metaphorically called "political animals", i.e., ministers who, after ending one tenure (without being dismissed or due to the normal duration of their term), return to new ministerial functions (some years later). Therefore, the "exit" of a minister from a ministerial tenure may not be his/her final farewell to his/her political life. Consequently, the dimensions increasing the hazard of his/her exit from a ministerial tenure can be different from those increasing the hazard of his/her exit from ministerial experiences. We will also analyze these differences.

\section{III - Estimating the hazard of a Portuguese Prime-Minister or Minister having his or her tenure in danger - an empirical analysis based on proportional hazards regression}

We now study by an appropriated and detailed way the political survival rate of a Portuguese Minister or Prime Minister in the Constitutional Governments (1976-2015). For this purpose, we also reviewed several works on the statistical analysis of duration models. We particularly recommend the works of Berlinski et al. (2007) and Bright et al. (2015), especially focused on political science. Additionally, our review of literature focused on the political survival of individuals (Park and Hendry, 2015) and also suggested a methodological framework based on proportional hazards $(\mathrm{PH})$ regressions.

The group of $\mathrm{PH}$ regressions is composed of the Cox $\mathrm{PH}$ regression and the parametric regression models (Ross, 2000; George et al., 2014). As Klein and Moeschberger (2005) observe, the Cox regression has been used in various scientific fields. This type of regression allows researchers to determine which individual characteristics (in our case, the characteristics of each Portuguese Minister or Prime-Minister) influence the survival of the subject in some risky situation (in this case, a Minister's presence in office).

Equation 1 exhibits the general form of the Cox proportional hazards regression (Berlinski et al., 2007; Bright et al., 2015):

$$
\lambda_{i}(t)=e^{x_{i} \beta} \times \lambda_{0}(t), \quad i=1,2, \ldots, n
$$

Equation 1 shows that, with $\mathrm{n}$ ministers being studied, the hazard rate (the probability of presence in office after t days, i.e.,) depends on the vector of the considered variables (x), the vector of the regression coefficients, and the baseline hazard (i.e., the probability of being in office when all of the explanatory variables are equal to 0$)$.

The regression coefficients can be interpreted as expressing the relationship between the proportional change that is expected in the hazard and the changes in the explanatory variables. Therefore, significant estimated coefficients higher than 1 relate to determinants that increase the hazard of shortening the political life (as minister) of a citizen; conversely, significant coefficients lower than 1 are associated with variables diminishing that hazard, and so those variables can be identified as variables contributing to a longer political term of each minister. 
In the class of Cox PH models, the baseline hazard does not depend on the explanatory variables; it depends only on $t$. Furthermore, the exponential component includes the explanatory variables but not the number of time periods (i.e., in this case, the number of days). Finally, the explanatory variables are time-independent (typically called the "proportional hazard assumption").

However, a strong assumption must hold: the proportional hazards assumption requires that the difference in log hazard associated with a change in each covariate is not time-dependent.

To test this assumption, we ran the test on the Schoenfeld residuals on functions of time. A non-zero slope indicates a violation of the proportional hazard assumption, which prompts the suggestion of retiring the covariates that were found to violate the assumption (Keele, 2010). The results of the tests on the Schoenfeld residuals are exhibited in the last rows of Tables 4-5.

However, as there are many and very different individuals in the sample, unobserved individual heterogeneity or other random effects in survival analysis can be an issue. Therefore, we also considered the use of frailty models to account for this possibility.

Therefore, following Omariba et al. (2007), the hazard model with frailty assumes that the risk of each individual $\mathrm{i}$ is dependent on the measured dimensions (as in Equation 2) and on random perturbations due to the unobserved effect of a certain characteristic $\mathrm{j}$ :

$$
h_{i j}\left(t \mid x_{i j}, \alpha_{j}\right)=\alpha_{j} h_{i j}\left(t \mid x_{i j}\right)
$$

The frailty $\alpha_{j}$ is a random variable taking on positive values, with the mean normalized to one and finite variance, which is assumed to follow a gamma distribution (Oakes, 1982). As Hanagal and Pandey (2015) suggested, "The gamma distribution is the most commonly used frailty distribution, largely because of its mathematical convenience; () Another choice is the inverse Gaussian distribution. The inverse Gaussian makes the population homogeneous with time, whereas for gamma the relative heterogeneity is constant". If this variance estimate is not statistically different from zero, then all the politicians have the same risk of exiting the functions; in contrast, if this estimate is statistically different from zero, then there is the suggestion that unmeasured/unmeasurable factors (Omariba et al., 2007) are interfering in the heterogeneous rate of failures observed for the cases.

We also estimated three types of parametric regression models, exploring the unobserved individual heterogeneity. According to these three types, we assumed three alternative forms of the survival distribution that are very common in demographics, medical science, and statistics - the exponential form, the Weibull form, and the Gompertz form (Ross, 2000; George et al., 2014). Available results will be exhibited if requested.

III.1 - Empirical findings

As mentioned above, we are studying two different types of 'political survival' of Prime-Ministers or Ministers. The first sense of 'political survival' relates to the survival of each minister within his/her government's tenure; the second sense of 'political survival' relates to each minister's survival in ministerial functions, considering not only the days in office within each government but also the cumulated days as Minister or as Prime-Minister. For instance, when Cavaco Silva ended his $3^{\text {rd }}$ term as PM (which lasted 1458 days, from the $31^{\text {st }}$ of October, 1991 to the $28^{\text {th }}$ of October, 1995) he reached a total of 4015 days in ministerial functions: 3643 days as PM (from 6/11/1985 to 28/10/1995) and 372 as Minister of Finance (from 3/1/1980 to 9/1/1981). 
Table 4 - Proportional Hazard of a Prime-Minister counting less days within a term

\begin{tabular}{|c|c|c|c|c|c|c|}
\hline Covariates & (1) Cox & (2) Cox & (3) Cox & $\begin{array}{l}\text { (4) Cox (with vv. Not vio- } \\
\text { lating the PH assumption) }\end{array}$ & $\begin{array}{l}\text { (5) Cox (with vv. Not vio- } \\
\text { lating the PH assumption) }\end{array}$ & $\begin{array}{l}\text { (6) Cox (with vv. Not vio- } \\
\text { lating the PH assumption) }\end{array}$ \\
\hline Years & 1976-2015 & 1976-1985 & 1986-2015 & 1976-2015 & 1976-1985 & 1986-2015 \\
\hline Yearly GDP real growth rate & $\begin{array}{c}0.701 * * \\
(0.250)\end{array}$ & $\begin{array}{c}0.951 \\
(0.271)\end{array}$ & $\begin{array}{c}0.612 * * * \\
(0.266)\end{array}$ & $\begin{array}{c}0.712 * * \\
(0.221)\end{array}$ & $\begin{array}{c}0.942 \\
(0.0242)\end{array}$ & $\begin{array}{c}0.617 * * * \\
(0.251)\end{array}$ \\
\hline $\begin{array}{l}\text { Yearly Change in unemploym. } \\
\text { rate }\end{array}$ & $\begin{array}{r}1.269 \\
(0.324)\end{array}$ & $\begin{array}{r}1.028 \\
(0.289)\end{array}$ & $\begin{array}{c}1.431 * * * \\
(0.138)\end{array}$ & $\begin{array}{l}1.276 \\
(0.388)\end{array}$ & $\begin{array}{l}1.033 \\
(0.301)\end{array}$ & $\begin{array}{c}1.442 * * * \\
(0.142)\end{array}$ \\
\hline Yearly Change in inflation rate & $\begin{array}{l}1.212 * * \\
(0.030)\end{array}$ & $\begin{array}{c}1.011 \\
(0.881)\end{array}$ & $\begin{array}{l}1.282 * * * \\
(0.042)\end{array}$ & $\begin{array}{l}1.231 * * \\
(0.038)\end{array}$ & $\begin{array}{l}1.013 \\
(0.882)\end{array}$ & $\begin{array}{c}1.272 * * * \\
(0.043)\end{array}$ \\
\hline Member of a political party & $\begin{array}{l}0.981 \\
(0.172)\end{array}$ & $\begin{array}{l}0.921 * * \\
(0.021)\end{array}$ & omitted & $\begin{array}{c}0.951 \\
(0.183)\end{array}$ & $\begin{array}{l}0.933 * * \\
(0.022)\end{array}$ & omitted \\
\hline $\begin{array}{l}\text { Number of past functions as a } \\
\text { member of the Gov'n'mt }\end{array}$ & $\begin{array}{c}0.923 * * \\
(0.031)\end{array}$ & $\begin{array}{c}0.991 \\
(0.231)\end{array}$ & $\begin{array}{l}0.911 * * \\
(0.062)\end{array}$ & $\begin{array}{c}0.928 * * \\
(0.029)\end{array}$ & $\begin{array}{c}0.994 \\
(0.332)\end{array}$ & $\begin{array}{c}0.918 * * \\
(0.063)\end{array}$ \\
\hline Density (birthplace) & $\begin{array}{l}0.918 * * \\
(0.039)\end{array}$ & $\begin{array}{c}0.913 * * * \\
(0.003)\end{array}$ & $\begin{array}{l}0.911 * * * \\
(0.002)\end{array}$ & $\begin{array}{l}0.903 * * \\
(0.040)\end{array}$ & $\begin{array}{l}0.915 * * * \\
(0.003)\end{array}$ & $\begin{array}{l}0.912 * * * \\
(0.002)\end{array}$ \\
\hline Education level & $\begin{array}{c}1.031 \\
(0.711)\end{array}$ & $\begin{array}{c}1.012 \\
(0.834)\end{array}$ & $\begin{array}{l}1.054 \\
(0.827)\end{array}$ & $\begin{array}{l}1.039 \\
(0.699)\end{array}$ & $\begin{array}{l}1.014 \\
(0.844)\end{array}$ & $\begin{array}{l}1.077 \\
(0.831)\end{array}$ \\
\hline Gender & $\begin{array}{c}0.001 \\
(0.771)\end{array}$ & $\begin{array}{c}1.231 * * * \\
(0.019)\end{array}$ & omitted & & & \\
\hline Parliamentary Majority & $\begin{array}{c}0.945 \\
(0.034)\end{array}$ & $\begin{array}{c}0.891 * * \\
(0.051)\end{array}$ & $\begin{array}{c}0.659 * * * \\
(0.041)\end{array}$ & $\begin{array}{c}0.932 \\
(0.038)\end{array}$ & $\begin{array}{c}0.892 * * \\
(0.049)\end{array}$ & $\begin{array}{c}0.668 * * * \\
(0.048)\end{array}$ \\
\hline$\%$ right-wing seats & $\begin{array}{l}1.040 * \\
(0.034)\end{array}$ & $\begin{array}{l}1.033 \\
(0.088)\end{array}$ & $\begin{array}{l}1.035 \\
(0.045)\end{array}$ & $\begin{array}{l}1.039 * \\
(0.033)\end{array}$ & $\begin{array}{l}1.032 \\
(0.091)\end{array}$ & $\begin{array}{c}1.035 \\
(0.041)\end{array}$ \\
\hline Age & $\begin{array}{l}1.003 \\
(0.032)\end{array}$ & $\begin{array}{l}1.022 \\
(0.035)\end{array}$ & $\begin{array}{l}1.032 \\
(0.032)\end{array}$ & & & \\
\hline After 1986 & $\begin{array}{c}0.042 * * * \\
(0.021)\end{array}$ & & & $\begin{array}{c}0.055 * * * \\
(0.025)\end{array}$ & & \\
\hline Number of Prime-Ministers & 20 & 9 & 11 & 20 & 9 & 11 \\
\hline Dummies Prime-Ministers & yes & yes & Yes & Yes & Yes & yes \\
\hline Log-likelihood & -2.211 & 0.612 & 0.434 & -2.261 & 0.713 & 0.652 \\
\hline AIC & 1.315 & 3.213 & 7.131 & 1.372 & 3.329 & 6.128 \\
\hline Overall Schoenfeld p-value & 0.116 & 0.762 & 0.805 & 0.226 & 0.812 & 0.856 \\
\hline
\end{tabular}

Source: elaborated by the authors.

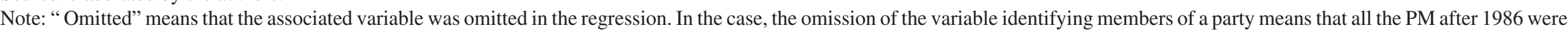
members of a Portuguese political party. Significance levels: $1 \%, * * * ; 5 \%, * * ; 10 \%$, *. 
Table 5 - Proportional Hazard of a Minister counting less days within a term

\begin{tabular}{|c|c|c|c|c|c|c|}
\hline Covariates & (1) Cox & (2) $\operatorname{Cox}$ & (3) Cox & $\begin{array}{c}\text { (4) Cox (with vv. Not violating } \\
\text { the PH assumption) }\end{array}$ & $\begin{array}{c}\text { (5) Cox (with vv. Not violating } \\
\text { the PH assumption) }\end{array}$ & $\begin{array}{c}\text { (6) Cox (with vv. Not violating } \\
\text { the PH assumption) }\end{array}$ \\
\hline Years & $1976-2015$ & $1976-1985$ & $1986-2015$ & $1976-2015$ & $1976-1985$ & $1986-2015$ \\
\hline Yearly GDP real growth rate & $\begin{array}{c}0.980 \\
(0.512)\end{array}$ & $\begin{array}{c}0.913 \\
(0.095)\end{array}$ & $\begin{array}{c}0.937 \\
(0.039)\end{array}$ & $\begin{array}{c}0.991 \\
(0.510)\end{array}$ & $\begin{array}{c}0.916 \\
(0.091)\end{array}$ & $\begin{array}{c}0.937 \\
(0.038)\end{array}$ \\
\hline $\begin{array}{l}\text { Yearly Change in unemploym. } \\
\text { rate }\end{array}$ & 0.999 & 0.994 & 10.004 & 0.992 & 0.990 & 1.005 \\
\hline & $(0.001)$ & $(0.031)$ & $(0.007)$ & $(0.001)$ & $(0.032)$ & $(0.007)$ \\
\hline Yearly Change in inflation rate & $\begin{array}{l}1.004 * * * \\
(0.0007)\end{array}$ & $\begin{array}{c}0.996 \\
(0.003)\end{array}$ & $\begin{array}{c}1.006 * * * \\
(0.008)\end{array}$ & $\begin{array}{l}1.003 * * * \\
(0.0006)\end{array}$ & $\begin{array}{c}0.994 \\
(0.004)\end{array}$ & $\begin{array}{c}1.006 * * * \\
(0.007)\end{array}$ \\
\hline Member of a political party & $\begin{array}{c}1.003 \\
(0.102)\end{array}$ & $\begin{array}{c}0.907 \\
(0.136)\end{array}$ & $\begin{array}{l}1.153 \\
(0.181)\end{array}$ & $\begin{array}{c}1.002 \\
(0.104)\end{array}$ & $\begin{array}{c}0.901 \\
(0.199)\end{array}$ & $\begin{array}{l}1.152 \\
(0.180)\end{array}$ \\
\hline $\begin{array}{l}\text { Number of past functions as a } \\
\text { member of the Gov'n'mt }\end{array}$ & $\begin{array}{c}0.971 \\
(0.069)\end{array}$ & $\begin{array}{c}0.952 \\
(0.078)\end{array}$ & $\begin{array}{c}0.963 \\
(0.071)\end{array}$ & $\begin{array}{c}0.972 \\
(0.071)\end{array}$ & $\begin{array}{c}0.959 \\
(0.079)\end{array}$ & $\begin{array}{c}0.961 \\
(0.070)\end{array}$ \\
\hline Density (birthplace) & $\begin{array}{c}1.011 \\
(0.023)\end{array}$ & $\begin{array}{l}1.041 \\
(0.036)\end{array}$ & $\begin{array}{c}0.969 \\
(0.029)\end{array}$ & $\begin{array}{c}1.012 \\
(0.022)\end{array}$ & $\begin{array}{l}1.040 \\
(0.037)\end{array}$ & $\begin{array}{c}0.962 \\
(0.030)\end{array}$ \\
\hline Education level & $\begin{array}{r}0.884 * * \\
(0.049)\end{array}$ & $\begin{array}{l}0.932^{*} \\
(0.021)\end{array}$ & $\begin{array}{c}0.891 * * \\
(0.051)\end{array}$ & $\begin{array}{c}0.897 * * \\
(0.052)\end{array}$ & $\begin{array}{l}0.934^{*} \\
(0.020)\end{array}$ & $\begin{array}{r}0.892 * * \\
(0.050)\end{array}$ \\
\hline $\begin{array}{l}\text { Number of ministries } \\
\text { simultaneously holding }\end{array}$ & $\begin{array}{l}1.298 \\
(0.269)\end{array}$ & $\begin{array}{c}0.939 \\
(0.107)\end{array}$ & $\begin{array}{l}1.537 * * * \\
(0.219)\end{array}$ & $\begin{array}{l}1.219^{* *} \\
(0.105)\end{array}$ & $\begin{array}{c}0.941 \\
(0.111)\end{array}$ & $\begin{array}{c}1.568 * * * \\
(0.222)\end{array}$ \\
\hline Gender & $\begin{array}{c}0.959 \\
(0.201)\end{array}$ & $\begin{array}{c}1.002 \\
(0.734)\end{array}$ & $\begin{array}{c}0.917 \\
(0.164)\end{array}$ & & & \\
\hline Parliamentary Majority & $\begin{array}{c}0.281 * * * \\
(0.044)\end{array}$ & $\begin{array}{c}0.273 * * * \\
(0.121)\end{array}$ & $\begin{array}{c}0.502 * * * \\
(0.097)\end{array}$ & $\begin{array}{c}0.459 * * * \\
(0.047)\end{array}$ & $\begin{array}{c}0.281 * * * \\
(0.131)\end{array}$ & $\begin{array}{c}0.664 * * * \\
(0.099)\end{array}$ \\
\hline$\%$ right-wing seats & $\begin{array}{c}0.950 * * * \\
(0.011)\end{array}$ & $\begin{array}{c}0.913 * * * \\
(0.028)\end{array}$ & $\begin{array}{c}0.932 * * \\
(0.012)\end{array}$ & $\begin{array}{c}0.931 * * * \\
(0.012)\end{array}$ & $\begin{array}{c}0.924 * * * \\
(0.014)\end{array}$ & $\begin{array}{c}0.928 * * * \\
(0.022)\end{array}$ \\
\hline Age & $\begin{array}{c}1.038 \\
(0.046)\end{array}$ & $\begin{array}{c}1.041 \\
(0.049)\end{array}$ & $\begin{array}{c}1.040 \\
(0.039)\end{array}$ & & & \\
\hline After 1986 & $\begin{array}{c}0.194 * * * \\
(0.029)\end{array}$ & & & $\begin{array}{c}0.287 * * * \\
(0.030)\end{array}$ & & \\
\hline Number of Ministers & 473 & 197 & 276 & 473 & 197 & 276 \\
\hline Dummies Ministers & yes & Yes & Yes & Yes & Yes & yes \\
\hline Log-likelihood & -2137.14 & -775.13 & -1041.62 & -2246.12 & -781.12 & -1044.26 \\
\hline AIC & 4292.3 & 1566.27 & 2101.38 & 4301.45 & 1592.81 & 2535.25 \\
\hline Overall Schoenfeld (p-value) & 0.564 & 0.229 & 0.387 & 0.589 & 0.301 & 0.463 \\
\hline
\end{tabular}

Source: elaborated by the authors.

Note: The interception was estimated but not exhibited here. The robust standard errors are between the parentheses. Significance levels: $1 \%$, ***; $5 \%$, **; $10 \%$, *. 
${ }^{4}$ Actually, the governments of non-members of political parties (the $3^{\text {rd }}$, led by Nobre da Costa, from 29/08/1978 to $22 / 11 / 1978$; and the $5^{\text {th }}$, led by Lourdes Pintasilgo, from $7 / 7 / 1979$ to $3 / 1 / 1980$ ) are clear examples of this short duration.
The following Tables (Tables 4-5) report the results of two specifications of the Cox proportional hazard analysis of our data (with all the covariates previously introduced, columns 1 to 3 ), or without the covariates violating the proportional hazard assumption -(columns 4 to 6 ), as well as the results of the estimations resulting from dividing the observations for the sub-samples composed of the observations prior to 1986 or after 1986 (as clearly suggested by the results from the tests of the equality of the survivor functions and by the statistical significance of the estimated coefficient for the dummy signaling the period after 1986). Table 4 presents the estimates of the Cox survival functions related to the PM; Table 5 presents the estimates of the Cox survival functions related to Portuguese Ministers.

Table 4 shows the estimates of our Equation 1, related to the days in office of Portuguese Prime-Ministers. In column 1, we observe that higher growth rates of GDP contribute to an increased number of days in office of Portuguese Prime-Ministers. The estimated coefficient means that there are approximately $30 \%$ fewer individuals exiting the function of Prime-Minister when the real growth rates of GDP are one percentage point higher. We also found the estimated coefficients for the number of past functions as a member of other governments and for the density of the birthplace. These findings suggest that PM with greater political experience in previous governments exhibit higher probabilities of survival in Portugal. The chosen proxy for the natural social capital (proxied by the density of the birthplace) has also been found to be statistically significant, suggesting that PM coming from more dense places tend to survive better in office. As expected, years characterized by more significant changes in the unemployment rate (especially after 1986 - column 3 of Table 4) or in the inflation rate tend to put the PM in a riskier situation.

If we split the sample, using the year 1986 as a breaking point, we clearly observe the importance of the variable related to the presence of a supporting parliamentary majority as a factor for increasing the duration of the number of days that a PM is in office (column 3 of Table 4). This follows a well-established result in the economic and political science literature (Chiru, 2015). Being a member of a political party significantly extended the days in office of Portuguese Prime-Ministers before $1986^{4}$.

Columns 4, 5 and 6 reveal that the estimates of the Cox proportional hazards of a Prime Minister show fewer days in office within each term, but now we omit the variables that we found violating the assumption of the proportional hazard (meaning that these variables are not time-independent). We found that gender is a variable violating the proportional hazard assumption ( $p$-value is 0.012). However, after omitting this variable, as suggested by Fischer et al., 2012 (for presidential systems), we did not find relevant changes in the estimates of the Cox survival functions for the Portuguese PM.

Table 5 shows the estimates related to the Cox Proportional Hazard model but now considers each individual's duration in ministerial offices.

In column 1 of Table 5, we can observe that abrupt changes in the inflation rate tend to shorten the tenure of a minister. Additionally, we also observed that right-wing majorities in the Parliament tend to increase the number of days in office of Portuguese ministers.

From a contrasting perspective, and still observing column 1 of Table 5, there are dimensions contributing to a significant extension of days in office. First, in the period after 1986 there are more ministers serving more days in each term than in the period before 1986. The estimated coefficient (0.194) is highly significant and its magnitude is impressive: its value means that the number of ministers leaving office after 1986 with a given tenure's length is 5 times less 
the number of ministers leaving office before 1986 with the same length. This follows Abrantes and Roldão (2014). In the period before 1986 - a period dominated by intense parliamentary turmoil and by the youth of the Portuguese democratic institutions - there were 15 governments (6 Provisory governments and 9 Constitutional governments). After 1986, with Portugal having been accepted as a member of the European Community and after the first experiences of parliamentary majorities based in just one party, governments' durations significantly increased, which contributed to longer ministerial terms.

Another dimension significantly increasing the probability of a former minister serving more days in office relates to his/her education. Ministers characterized by a higher level of education (e.g., holding a Ph.D. or being Full Professors) have tended to have longer tenures, following Fischer et al. (2012).

As also found highly significant was the coefficient estimated for the dummy signaling the periods after and before 1986, we considered it important to split the sample by checking this partition. Therefore, column 2 exhibits the results of the Cox PH Model for the years before 1986, and column 3 exhibits the results for the years after 1986 .

After conducting tests of the validity of the proportional hazard assumption for all the covariates previously analyzed in Table 5, it was found that the dummy variable related to gender violates the proportional hazard assumption (p-value lower than 5\%). Therefore, following authors such as Park and Hendry (2015), we have to re-estimate the Cox PH model without the violating variables (in this case, without gender). Columns 4,5 and 6 of Table 5 show the obtained results. These results are not significantly different than the results exhibited in columns 1, 2 and 3 of Table 5. We also observe that age influences the duration of Portuguese ministers in office: older ministers tend to serve shorter times in office.

When working with survival models, it is also advisable to run additional regressions and to relax the proportional hazard assumption of the Cox survival models (Park and Hendry, 2015). Therefore, we also assumed different distributions of the survival time using established parametric forms. We generated tables (available if requested) exhibiting the estimates of the survival of Portuguese PM and of Portuguese Ministers within each tenure and in the political life of ministerial functions, assuming three different distributions of the survival time - an exponential distribution (based on a constant hazard rate across time), a Weibull distribution (given that the log of the hazard is a linear function of the log of time), and a Gompertz(-Makeham), assuming that the log of the hazard is a linear function of the time. More details about the differences in these distributions are provided by Ross (2000) or George et al. (2014). As previously suggested, we are going to explore the possibility of unobserved individual heterogeneity and its relevance for the different distributions. Following Hanagal and Pandey (2015), we are going to assume a gamma distribution for

${ }^{5}$ We have also observed the differences when using an inverted gaussian distribution for the variance of the frailty. However, there are no statistically significant differences. Additional evidences are available under request. the variance of the frailty variable ${ }^{5}$.

Generally, the results from these Tables follow those of Table 4 to Table 5. Having a supporting parliamentary majority (composed of right-wing forces) in the period after 1986 clearly increases the survival of Portuguese PM and Ministers. Age has an estimated significant effect in the opposite direction of the level of education in terms of cumulated length in ministerial offices -, we found that getting older diminishes the survival hazard in ministerial functions and that having more education contributes to a longer political life in Portugal.

The estimated values of $\theta$ (variance parameter associated with the frailty effect in the models) are not statistically significant considering the exponential form or the Weibull form of the survival distribution. However, the estimated 
values for $\theta$ (considering a Gompertz form of the survival distribution) vary between 1.234 and 1.834 (considering a Gamma distribution of the frailty) in these Tables (available if requested). These values are statistically significant, revealing that unobserved characteristics of the cases also explain the heterogeneity of survival/failures of Portuguese ministers. This converges with studies in literature like Fischer et al. (2012) or Fedeli et al. (2014).

III.2 Robustness checks - do different ministries ensure higher political survival rates?

After studying the dimensions influencing the political survival of Portuguese Ministers and Prime Ministers, and after considering the differences in the periods in which each individual was in office, the differences in each tenure and in the accumulated number of days in ministerial functions of each minister, and the different distributions of survival time, we now explore the robustness of these results in additional directions. We constructed additional Tables (available if requested) which provide the results obtained after including the dummies identifying each group of ministries in the $\mathrm{PH}$ models.

By including the dummies identifying the groups of Portuguese Ministries already discussed, we have not found any relevant changes in the estimated coefficients if we compare them with the coefficients in Tables 4-5, namely the absence of statistical significance of the estimated coefficients for the dummies in the estimations of the $\mathrm{PH}$ models for survival within legislative tenures. Therefore, we cannot ensure that in considering the duration within each tenure, a certain group of ministries will provide longer terms.

However, there is evidence that the Ministries for the Autonomous Regions of the Azores and Madeira contributed to a higher number of cumulated days in office (columns 4, 5 and 6); from a contrasting perspective, holding office in Ministries focused on specific policies (like the Ministry for Administrative Reform or the Ministry for European Integration) seems to be more lethal in terms of pursuing future ministerial functions. Once again, the statistical significance of $\theta$ suggests that the unobserved individual heterogeneity may play an important role for explaining the different survival rates if we consider a Gompertz form for the survival distribution.

\section{IV - Conclusions, Political Implications and Further Research}

This work has focused on the political survival of Portuguese Ministers and Prime Ministers. Using Cox Proportional Hazard Models and different specifications of the distribution of survival time (an exponential, a Weibull, and a Gompertz-Makeham distribution), we achieved relevant results for explaining the heterogeneous survival rates of the more than 400 Ministers who have held offices since 1976 (i.e., since the $1^{\text {st }}$ Constitutional Government).

We used the conventional measure, and for each minister we counted the number of consecutive days in term.

Our results highlight the relevance of parliamentary majorities in the period after 1986, the importance of belonging to a political party, and the importance of higher education for ministers expecting longer tenures. Even if we consider the cumulated number of days in ministerial office (whose results and tables are available if requested), these dimensions are still found to be statistically significant. However, having had past ministerial experiences is an important variable for increasing the accumulated duration in office, meaning that "political animals" tend to have greater chances of being invited (and often invited again) to fulfill ministerial functions. We also observed that being a minister of the Republic for the Autonomous regions (of the Azores or Madeira) tended to ensure 
a longer political life; conversely, being in charge of a Ministry focused on specific policies (e.g., for Administrative Reform or for Equality) has been shown to not ensure many days in office.

This work suggests three major implications. The first relates to the challenge of stability and of political maturity that was observed in Portugal after 1986. On the one hand, this political stability significantly increased the duration of ministerial terms. However, it also contributed to the appearance of several individuals who accumulated days in office in different governments, which can be discussed as a relevant challenge to the renewal of political groups. Second, 'independent' ministers (i.e., not affiliated with any party) may expect a shorter duration in office. If, according to one perspective, being a member of a party is usually seen as a mark of the enlarged social capital of the minister, from another perspective, our results suggest that 'independent' ministers exhibit a higher frailty of exiting sooner. Finally, the role of parliamentary majorities seems very influential for explaining the different durations of Portuguese Ministers. This implies that the same pattern of action by a minister may be less scrutinized in parliamentary majorities than in parliamentary minorities, which raises several concerns about the effectiveness of the Parliamentary institutions.

The insights here highlighted are interesting contributions for improving our understanding about the addressed topics, namely for the Portuguese context and specifically for the period considered. This work is in line with the results found, for instance, by Soyland (2017) for the Norwegian context and by Moury and Standring (2017) for the Portuguese framework. In these fields it is always important to be aware about the world changes and dynamics, namely those from the British reality, including for the political parties (Quinn, 2019).

We propose four major challenges for extending the present study. The first challenge regards the role of individual/fiscal scandals in the abrupt end of ministerial functions in some cases in Portugal, considering, also, works about these topics from other realities, as the British (Berlinski et al., 2012), Latin American democracies (Camerlo and Pérez-Liñán, 2015) and when the chief of the executive is a prime minister or a president (Dewan and Myatt, 2007). Detailing the nature of these scandals, we will be able to observe which scandals are more lethal for the political survival of some ministers and which scandals are more insignificant. The second challenge regards the possibility of including some 'prestige indicators' that some media units have already produced for some periods in Portugal and focusing on the performance of ministers and of other political agents. The third challenge suggests that we explore the interactions between some of our variables (e.g., gender and education or gender and strategic ministerial office) to refine the findings presented in this discussion, considering studies as, for example, that developed by Escobar-Lemmon and Taylor-Robinson (2016). Finally, the fourth challenge relates to the possibility of enhancing the analysis of the duration dependence issue. Given the statistical significance of the Weibull parameter in the results we achieved, there are additional stimuli to discuss how likely ministers are to leave the office as a certain time in office is reached, following, as instance, the work of Castro and Martins, 2013). Following this opportunity, we will also be able to properly discuss the form of the tenures (a log form, a polynomial of tenure, or the use of dummy variables).

Paulo Mourão (paulom@eeg.uminho.pt) is PhD in Economics by University of Minho. 


\section{References}

Abrantes, P. \& Roldão, C., 2014. Faces and metamorphoses of power: a sociography of the Portuguese ministers of education in the democratic era. Educação e Pesquisa, 40(4), pp.1045-1060. DOI: http://dx.doi.org/10.1590/s1517-97022014041384

Afonso, A., 2013. Anatomy of a Fiscal Débacle: The Case of Portugal. ISEG Economics Working Paper No. 01/2013/DE/UECE. Available at SSRN: https://ssrn.com/ABSTRACT =2194556. Accessed at: 22.07.2020. DOI: $10.2139 / \mathrm{ssrn} .2194556$

Akarca, A. T., \& Andrianacos, D., 2006. Taxes, Transfers, and Voter Behavior in U.S. Midterm Elections. International Advances in Economic Research, 12(4), 468-474. DOI: 10.1007/s11294-006-9041-3

Almeida, M.A.P., 2008. Party politics in Portugal - Municipalities and central government. European Societies, 10(3), pp. 357-378. DOI: 10.1080/14616690701771813

Almeida, P.T. \& Pinto, A.C., 2002. Portuguese Ministers, 1851-1999: Social Background and Paths to Power. South European Society and Politics, 7(2) pp. 5-40. DOI: 10.1080/13608740708539625

Berlemann, M. \& Enkelmann, S., 2014. The economic determinants of U.S. presidential approval: A survey. European Journal of Political Economy, 36(s/n), pp. 41-54. DOI: 10.1016/j.ejpoleco.2014.06.005

Berlinski, S., Dewan, T., \& Dowding, K., 2012. Accounting for Ministers: Scandal and Survival in British Government 1945-2007. Cambridge: Cambridge University Press, 1st Edition edition, 208 pp. DOI: 10.1017/cbo9780511980046

Berlinski, S., Dewan, T., \& Dowding, K., 2007. The length of ministerial tenure in the United Kingdom, 1945-97. British Journal of Political Science, 37(2), pp. 245-262. DOI: 10.1017/s0007123407000415

Bright, J., Döring, H., \& Little, C., 2015. Ministerial Importance and Survival in Government: Tough at the Top? West European Politics, 38(3), pp. 441-464. DOI: 10.1080/01402382.2014.993166

Bucur, C., 2013. Who fires ministers? A principal-agent approach to ministerial deselection. PhD Dissertation, Dublin, Dublin City University. Available through https://core.ac.uk/download/pdf/147606273.pdf. Accessed at: 22.07.2020.

Camerlo, M. \& Pérez-Liñán, A., 2015. Minister Turnover, Critical Events, and the Electoral Calendar in Presidential Democracies. The Journal of Politics, 77(3), pp. 608-619. DOI: 10.1086/681028

Carneiro, A., Guimaraes, P., \& Portugal, P., 2009. Real Wages and the Business Cycle: Accounting for Worker and Firm Heterogeneity. CEF.UP Working Papers 0903, Universidade do Porto, Faculdade de Economia do Porto. Available through https://ideas.repec.org/p/iza/izadps/dp4174.html. Accessed at: 22.07.2020.

Castro, V. \& Martins, R., 2013. Is there duration dependence in Portuguese local governments' tenure? European Journal of Political Economy, 31(1), pp. 26-39. DOI: 10.1016/j.ejpoleco.2013.03.004

Chiru, M., 2015. Early Marriages Last Longer: Pre-electoral Coalitions and Government Survival in Europe. Government and Opposition, 50(2), pp. 165-188. DOI: 10.1017/gov.2014.8

Correa d'Almeida, A. \& Mourao, P., 2015. The Irrelevance of Political Parties' Differences for Public Finances - Evidence from Public Deficit and Debt in Portugal (1974 - 2012). European Review, 25(4) pp.560-587. DOI: $10.1017 / \mathrm{s} 1062798717000291$

Dewan, T. \& Myatt, D.R., 2007. Scandal, protection, and recovery in the cabinet. American Political Science Review, 101(1), pp. 63-77. DOI: 10.1017/s0003055407070025

Downs, A., 1957. An Economic Theory of Democracy. New York, Harper and Row.

Dowding, K. \& Dumont, P., 2016. The Selection of Ministers around the World. Routledge, 1 edition, 318 p. DOI: $10.4324 / 9781315757865$

Druckman, J.N. \& Warwick, P.V., 2005. The missing piece: Measuring portfolio salience in Western European parliamentary democracies. European Journal of Political Research, 44(1) pp. 17-42. DOI: 10.1111/j.1475-6765.2005.00217.x

Escobar-Lemmon, M.C. \& Taylor-Robinson, M.M., 2016. Will Women in Presidential Cabinets be Power Players or Abundant Tokens? Oxford: Oxford University Press, $1^{\text {st }}$ edition, 320 p. DOI: 10.1093/acprof:oso/9780190491420.001.0001

Fedeli, S., Forte, F., \& Leonida, L., 2014. The law of survival of the political class: an analysis of the Italian parliament (1946-2013). European Journal of Political Economy, 35(s/n), pp. 102-121. DOI: 10.1016/j.ejpoleco.2014.05.001

Fernandes, J. M. \& Magalhaes, P., 2015. Government survival in semi-presidential regimes. European Journal of Political Research, 55(1) pp. 61-80 DOI: 10.1111/1475-6765.12116

Fielding, D., 2000. Social and economic determinants of English voter choice in the 1997 general election. Public Choice, 102(s/n), pp. 271-295.

Fischer, J., Dowding, K., \& Dumont, P., 2012. The duration and durability of cabinet ministers. International Political Science Review, 33(5), pp. 505-519. DOI: 10.1177/0192512112462971

George, B., Seals, S., \& Aban, I., 2014. Survival analysis and regression models. Journal of Nuclear Cardiology, 21(4), pp. 686-694. DOI: 10.1007/s12350-014-9908-2

Han, K.J., 2015. When Will Left-Wing Governments Introduce Liberal Migration Policies? An Implication of Power Resources Theory. International Studies Quarterly, 59(3), pp. 602-614. DOI: 10.1111/isqu.12156

Hanagal, D. \& Pandey, A., 2015. Inverse Gaussian Shared Frailty Models with Generalized Exponential and Generalized Inverted Exponential as Baseline Distributions. Journal of Data Science 13(3), pp.569-602.

Hardouvelis, G. \& Thomakos, D., 2008. Consumer Confidence and Elections. Discussion Paper 6701, CEPR. Available through https://ideas.repec.org/p/cpr/ceprdp/6701.html. Accessed at: 22.07.2020.

Hessami, Z., 2010. The Size and Composition of Government Spending in Europe and Its Impact on Well-Being. Kyklos, 63(3), pp. 346-382. DOI: 10.1111/j.1467-6435.2010.00478.x 
Keele, L., 2010. Proportionally Difficult: Testing for Nonproportional Hazards in Cox Models. Political Analysis, 18(2), pp. 189-205. DOI: 10.1093/pan/mpp044

Klein, J. P., \& Moeschberger, M. L., 2005. Survival Analysis: Techniques for Censored and Truncated Data. New York: Springer Verlag.

Leruth, L. \& Paul, E., 2006. A Principal-Agent Theory Approach to Public Expenditure Management Systems in Developing Countries. IMF Working Paper, WP/06/204, International Monetary Fund. Available through https://www.imf.org/external/pubs/ft/wp/2006/wp06204.pdf. Accessed at: 22.07.2020.

Lewis-Beck, M.S. \& Stegmaier, M., 2013. The VP-function revisited: a survey of the literature on vote and popularity functions after over 40 years. Public Choice, 157(3-4), pp. 367-385. DOI: 10.1007/s11127-013-0086-6

Mattozzi, A. \& Merlo, A., 2005. Political Careers or Career Politicians? PIER Working Paper 05-032, Penn Institute for Economic Research. Available through https://econpapers.repec.org/paper/penpapers/05-032.htm. Accessed at: 22.07.2020.

Mayer, W. \& Raimondos-Møller, P., 2003. The Politics of Foreign Aid: A Median Voter Perspective. Review of Development Economics, 7(2), pp. 165-178. DOI: 10.1111/1467-9361.00183

Mourao, P \& Martinho, V., 2016. Discussing structural breaks in the Portuguese regulation on forest fires - An economic approach. Land Use Policy, 54(s/n), pp. 460-478. DOI: 10.1016/j.landusepol.2016.03.003

Mourao, P., 2013. The Messenger of Inflation - How Media Change Political Competition. Applied Economics Letters, 20(3), pp. 267-271. DOI: 10.1080/13504851.2012.690843

Moury, C. \& Standring, A., 2017. Going beyond the Troika': Power and discourse in Portuguese austerity politics. European Journal of Political Research, 56(3), pp. 660-679. DOI: 10.1111/1475-6765.12190

Oakes, D., 1982. A model for association in bivariate survival data. Journal of Royal Statistical Society: Series B (Methodological), 44(3), pp. 414-422. DOI: 10.1111/j.2517-6161.1982.tb01222.x

Omariba, D., Beaujot, R. \& Rajulton, F., 2007. Determinants of infant and child mortality in Kenya: an analysis controlling for frailty effects. Population Research and Policy Review, 26(3), pp.299-321. DOI: 10.1007/s11113-007-9031-z

Park, S. \& Hendry, D., 2015. Reassessing Schoenfeld Residual Tests of Proportional Hazards in Political Science Event History Analyses. American Journal of Political Science, 59(4), pp. 1072-1087. DOI: 10.1111/ajps.12176

Quinn, T., 2019. The Conservative Party's leadership election of 2016: choosing a leader in government. British Politics, 14(1), pp. 63-85. DOI: 10.1057/s41293-018-0071-2

Reto, L. \& Sá, J., 2016. Esquerda e Direita em Portugal, Consensos, Divergências e Antagonismos. Lisboa: Livros Horizonte.

Richardson, B., 2001. Japan's '1955 System' and Beyond. In L. Diamond \& R. Gunther, (eds.) Political parties and democracy. John Hopkins University Press.

Rose, J., 2014. The Public Understanding of Political Integrity: The Case for Probity Perceptions. London: Palgrave Macmillan.

Ross, S.M., 2000. Introduction to Probability Models, Seventh Edition. Academic Press.

Sardica, J.M., 2011. O Século XX Português. Lisboa: Texto Editores.

Savage, M., Tampubolon, G. \& Warde, A., 2004. Social Capital and Political Activism: A Social Network Approach. In J. Franklin, (ed.). Politics, Trust and Networks: Social Capital in Critical Perspective. London: London South Bank University.

Seyd, B., 2015. Book Review: General Politics: The Public Understanding of Political Integrity: The Case for Probity Perceptions. Political Studies Review 13 (2) pp. 289-289. DOI: 10.1111/1478-9302.12087_83

Soyland, M.G., 2017. Survival of the Ministers: On Ministerial Durability in Postwar Norway. Scandinavian Political Studies, 40(2), pp.182-206. DOI: 10.1111/1467-9477.12086

Veiga, F.J. \& Veiga, L.G., 2001. The determinants of vote intentions in Portugal. NIPE WP 6/2001. NIPE, University of Minho. Available through https://repositorium.sdum.uminho.pt/bitstream/1822/1455/1/Public_Choice_March_2004.pdf. Accessed at: 22.07.2020.

Veiga, F.J. \& Veiga, L.G., 2003. Economia, popularidade e intenções de voto em Portugal: uma análise longitudinal com dados agregados. NIPE Working Paper series, 5/2003, Universidade do Minho - Núcleo de Investigação em Políticas Económicas, Portugal. Available through http://repositorium.sdum.uminho.pt/handle/1822/1364. Accessed at: 22.07.2020.

Wissenburg, M. \& Schlosberg, D. 2014. Political Animals and Animal Politics. London: Palgrave-Macmillan.

\section{Other sources}

Constitution of the Portuguese Republic (1976). Available through https://dre.pt/constitution-of-the-portuguese-republic. Accessed at: 23.07.2020.

CVCE (2016). Biografias de personalidades portuguesas. CVCE, Luxembourg.

FFMS (2016). Cronologias. Fundação Francisco Manuel dos Santos/FFMS, Lisboa. Available through http://cronologias.ffms.pt/eventos?event=36405. Accessed at: 24.06.2019.

INE (2016). Several statistics. Available through https://www.ine.pt/xportal/xmain?xpid=INE\&xpgid=ine_base_dados. Accessed at: 23.07.2020.

PORDATA (2016). Several statistics. Available through http://www.pordata.pt/. Accessed at: 23.07.2020. 


\section{Newspaper articles}

Silva, M., 2015. “Quem foi ministro mais tempo? E quais os Governos que duraram menos?”. Paço de Arcos. Expresso October 31, 2015. Available through http://expresso.sapo.pt/politica/2015-10-30-Quem-foi-ministro-mais-tempo--E-quais-os-Governos-que-duraram-menos-- . Accessed at: 22.07.2020.

Soares, M. (2016). "Quatro décadas de democracia: 31 mulheres ministras e 467 homens". Paço de Arcos. Expresso. Available through http://multimedia.expresso.pt/240415_mulheres_no_poder/. Accessed at: 22.07.2020.

Ministros Portugueses como sobreviventes políticos: uma análise empírica dos primeiros 20 governos constitucionais

RESUMO Introdução: Avaliamos o risco proporcional de primeiros-ministros e ministros portugueses deixarem o cargo. Materiais e Métodos: Utilizamos dias consecutivos como ministro para cada um dos 432 cidadãos que exerceram a função ministerial desde 1976. Resultados: Explorando várias divisões desse universo, concluímos que indivíduos apoiados por maiorias parlamentares, que serviram depois de 1986, que possuíam qualificações académicas mais altas e que eram membros de partidos políticos apresentaram menores riscos de serem exonerados do cargo. Por outro lado, ser uma pessoa com mais idade, servindo em condições econômicas adversas, assumindo vários ministérios simultaneamente e sendo encarregado de ministérios específicos, não garantiu períodos políticos mais longos para os ministros portugueses. Discussão: Além de ser a primeira avaliação empírica de todos os ministros portugueses após 1974, este trabalho mostra como as habilitações mais altas são ativos importantes para os mandatos dos ministros e como as crises econômicas são altamente estimulantes para as mudanças dos gabinetes em Portugal, o que corresponde ao padrão observado na maioria dos regimes democráticos recentes.

PALAVRAS-CHAVE: gabinetes ministeriais; governos constitucionais portugueses; sobrevivência política; risco proporcional; gênero.

This is an Open Access article distributed under the terms of the Creative Commons Attribution Non-Commercial License which permits unrestricted non-commercial use, distribution, and reproduction in any medium provided the original work is properly cited.

A produção desse manuscrito foi viabilizada através do patrocínio fornecido pelo Centro Universitário Internacional Uninter à Revista de Sociologia e Política. 